UDK 811.163.6’42-055

Izvorni znanstveni članak

Prihvaćeno za tisak: 10. rujna 2018.

https://doi.org/10.22210/suvlin.2018.086.07

\author{
Damjan Popič, Vojko Gorjanc \\ University of Ljubljana, Faculty of Arts \\ damjan.popic@ff.uni-lj.si,vojko.gorjanc@ff.uni-lj.si
}

\title{
Challenges of adopting gender-inclusive language in Slovene
}

\begin{abstract}
This paper presents the challenges of introducing gender-inclusive language in Slovene in last two decades. Within this scope we focus on the progressive developments in the sphere of adopting gender-inclusive language and present the entire background as well as the counter-forces (and their line of argumentation), working to eradicate the efforts for employing gender-inclusive language in the Slovenian society. We thus present the main tendencies as well as linguistic elements aiming to facilitate gender-inclusive language in the Slovenian society, focusing mainly on the use of the underscore within our analysis. We analyze two manually constructed corpora with texts harvested from Slovenian websites of the organizations that use the underscore in order to employ genderinclusive language. We show that the use of the underscore is continually growing, in spite of the efforts to downplay its value by challenging its usability and ubiquity.
\end{abstract}

\section{Introduction}

This paper presents the possibilities for enabling discursive practices for increasing the visibility of different genders in Slovene, focusing on one of the possibilities in the analytical section of the paper. This possibility, i.e. the underscore, was introduced into the Slovenian discourse not only as an effort for a greater visibility of both genders, which was the usual practice of the initial attempts of employing gender-inclusive language, but also with the aim for doing away with the binary understanding of gender and using traditional linguistic elements innovatively, so that all genders are included in discourse.

Different languages have different ways of expressing gender pluralism. Unlike, for instance, English, Slovene is quite limited in this respect, also due to its highly inflective nature and its prescriptive tradition (cf. Toporišič 2004), which has not paid much attention to gender pluralism (and is, in part, perhaps wary of it even today). In addition, the introduction of gender-sensitive language has re- 
ceived much public scrutiny, especially from the right-wing media. ${ }^{1}$ In the following section, we briefly describe the framework into which we place our research. Our intention is not to provide a holistic analysis of every attempt at introducing gender-sensitive discursive practices and the discussions arising from it, but to present them in order to enable better understanding of one of the attempts, which is at the core of our research.

1.1 In addition to the public scrutiny exercised focused on the use of innovative linguistic elements for enabling gender inclusion, there has recently also been an intensive public outcry in Slovenia as the Senate of the Faculty of Arts, University of Ljubljana, decided to use the feminine forms as generic and gender-inclusive in all its internal normative documents in the following three years. After this period, the feminine and masculine shall be used interchangeably. ${ }^{2}$ Even though this has been the standard practice at the Faculty of Social Work, University of Ljubljana, for over 15 years and Slovenia already saw the publication of a scientific monograph (Hofman 2017) dealing with scientific careers from the perspective of gender (and this monograph employed the same discursive practice, more than one year prior to the Senate's decree), it was exactly the decision of the Faculty of Arts that spurred public debate. In actuality, it was the first public response to this decision that really incited a heated debate: this was a text marked by traditional linguistics as well as being explicitly manipulative in nature, published by one of the central Slovenian dailies - Delo (Ahačič 2018). ${ }^{3}$ The author failed to take the actual decree and its impact on the entire genre into account, and instead deliberated on the possible consequences for language use that had not been intended nor made possible by the decree.

1 Cf. the heading of an article in response to the publication of the Guidelines for Reporting on Transsexualism (Koletnik and Grm 2017), which was published in the right-wing news outlet NOVA24: "Degenerate Left Lecturing the Media How to Write about Transsexuals” (http://nova24tv.si/slovenija/politika/izrojenalevica-poucuje-novinarje-kako-naj-pisejo-o-transseksualcih/ (Last accessed: 9 October 2018).

2 The decree of the Faculty of Arts served as a basis for the decision of the Equal Opportunities in Science Commission at the Ministry of Education, Science and Sport of the Republic of Slovenia, which understood the decree as "ethically motivated attempt of an institution to challenge the users of these texts to rethink their attitude towards unwanted sexually discriminatory features in language, as well as to remind the society as a whole of its permanent commitment to eradicate morally unjustified discrimination, wherever possible, by using public choices and policies." The commission is therefore "welcoming the decree and sees it as an important contribution to finding non-discriminatory language uses in public institutions of the Republic of Slovenia." (http://www.mizs.gov.si/fileadmin/mizs.gov.si/pageuploads/novice/pdf/Izjava_ Komisije_uporaba_zenske_spolne_oblike_v_pravilnikih_FF_UL.pdf?fbclid=IwAR1PLmd8-EwlROc9u1zFs9vnnNz73n8ki32TNrOm3tisaTI0pnUq0szffiI; last accessed: 22 November 2018).

3 As the number of responses of members of the traditional academic institutions bearing the standardizing power in Slovenia (cf. Ahačič 2018) as well as that of traditional linguists (cf. Štumberger 2018a) demonstrates, linguistic arguments in the framework of standard language ideology are also used for manipulative purposes. The publication in the most influential Slovenian daily newspaper, in which the author is also a regular contributor, was of key importance for further discussion. This was namely the use of discourse from the position of authority of the media outlet in which the author is a regular columnist and used the medium to gain discursive authority, i.e. a situation in which it is the easiest for the readers to accept the discursive positions of the author as self-evident (Katnić Bakaršić 2012: 6-7). 
The ensuing debate failed to address merely the linguistic issues, but instead revealed to what extent the binary heteronormative model, imbued with patriarchalism, is rooted in the Slovenian society. In addition, the debate revealed the ideological positions within the Slovenian linguist community, especially within the field of Slovene studies in relation to its standard-language core. Namely, it became apparent that standard-language ideology is linked to other ideological positions within the society that contradict equality, not just of women but also of other social groups, e.g. the members of the LGBTQ+ community (Gorjanc 2018), whereas the linguistic discourse is merely a pretense for defending these ideological positions (Šorli 2018). In this paper, we do not deal with the analysis of this particular discursive practice, but instead aim to present an attempt of introducing an innovative use of traditional linguistic elements for a more gender-inclusive language use.

As we are focusing on a particular linguistic element, i.e. the underscore, within the scope of corpus analysis, we also present the background of adopting this means of expression as well as its reception in the Slovenian linguistic circles.

1.2 In Slovene, the slash has been the prevalent means of expressing gender binarism (i.e. študent/-ka), but recently a number of institutions have begun using the underscore. Its function is to express gender pluralism, thus opening a space for the visibility of non-binary and other gender identities. For example, the TransAkcija Institute 4 use the underscore in a feminist manner, i.e., they use the generic feminine gender, or use the feminine root of the word wherever the feminine form is not directly derived from the masculine by merely adding the feminine suffix to it (cf. the past tense of the verb "(he/she) was": bil_a, wherein bil is the masculine and bila the feminine, and the form "they were" (bile_i); in the latter case, the root of the word is bil-, the male suffix is $-i$, and the feminine - $e$. Thus, the female form is that of precedence. As already pointed out, there have been monographs using the underscore published by the Scientific Research Centre of the Slovenian Academy of Sciences and Arts (Hofman 2017; Golež Kaučič 2018), while it is also used by the (left-leaning) political weekly in Slovenia, Mladina.

The implementation of the underscore as a means of adopting gender-inclusive language in Slovene has been met with severe opposition, vocal as well as silent, and this also holds true for the wider purview of the initiatives for a more gender-neutral Slovene. For this reason, we present the background of implementing gender-inclusive language in Slovenia following the independence, focusing mostly on the introduction of the underscore. We present the arguments for and against its adoption as well as argue that it is used extensively as well as consistently within the public dealing with LGBTQ+ rights. We demonstrate this by means of corpus analysis with two comparable corpora built specially for this purpose.

4 http://transakcija.si/english/ (Last accessed: 9 October 2018) 


\section{Adopting gender-inclusive language in Slovene}

The Slovenian pre-structuralist (Bajec et al. 1956) as well as structuralist linguistics (Toporišič 1976) mostly dealt with the question of gender in terms of a grammatical category. The authors of the pioneering attempts aiming for a linguistic description surpassing the traditional view of gender by employing non-structuralist theoretical and methodological underpinnings, especially those dealing with pragmatics (Mečkovska 1980: 211-212), were indeed recognized for introducing a new perspective, more closely linked to the practical use in texts. At the same time, the assessments of these new attempts were largely confined to the authors' own language-systemic conceptual beliefs (Toporišič 1981: 80-81). Language descriptions thus for the most part sporadically described its use, e.g. the precedence of the feminine forms when referring to women, as in Ana je arhitektka instead of Ana je arhitekt ('Ana is an architect'; Toporišič 1976: 202; Toporišič 2004: 266). Comparative studies between Slavic languages dealing with defining gender by means of feminine nouns in Slovene have shown that "almost in all cases feminine nouns are used, normally without any notion of stylistic or expressive undertone" (Mečkovska 1980: 212). This was not the case with other Slavic languages, especially East Slavic languages (Mečkovska 1980: 211).

Somewhat different to the mainstream approach in the grammatical description was the approach of the Slovenian lexicography. Its core members, comprising the team of lexicographers working on the Dictionary of Literary Slovene (19701991), based their work on the presumption of the generality of the masculine grammatical gender. At the same time, they described male actants with masculine classifications, and actually omitted women from linguistic description (Gorjanc 2005: 206), as they understood them merely as the feminine grammatical form and only referred to them with links to the existing descriptions for men with the explanation "the feminine form of" (Gorjanc 2017: 59). However, a section of Slovenian specialized lexicographers intentionally introduced feminine forms. This is especially true for those dictionaries in which actants are of special significance for defining terminology, such as the Theatre Terminology Dictionary (Sušec Michieli et al. 2007) as well as several others (Trojar and Žagar Karer 2013: 460). In this respect, the Slovenian military terminology in the Military Dictionary (1977) represents a positive breaking point, as all the forms for actants within the military consistently include feminine forms (Korošec 1995: 28). Even though the lexicographic practice was amended for the second edition of the Dictionary of Literary Slovene (2014), as the dictionary gives individual explanations for female actants (Kern 2015: 148), in line with the practice of the Dictionary of Newer Words in Slovene (2014), it is still far away from being socially acceptable in terms of linguistic description of women, as it fortifies the stereotypical view of the differences between the genders all the while failing to consider the modern lexicographic practice or the discursive reality (Gorjanc 2017: 109). 
The first big step in the study of gender in the Slovenian linguistics was taken at a discussion on non-sexist language in the Slovenian society in mid-90s. This was first and foremost a consequence of the Slovenian accession into European and Euro-Atlantic integrations, especially within the Slovenian efforts for joining the European Union. From the mid-1980s, when the Resolution on policy and strategies for achieving equality in political life and in the decision-making process (1986) was passed, the European political space discussed and passed political decisions that aimed for equality between the sexes, and the Slovenian discussion was a direct response to the Council of Europe's document Recommendation no. $R(90) 4$ of the Committee of ministers to member states on the elimination of sexism from language (1990), which addressed linguistic issues. The politically motivated discussion significantly transformed the linguistic discourse as well. Although the traditional view of the issue of gender among the main points of the discussion could not be avoided, these points nevertheless shifted the center of the discussion towards language use, problematized the generality of the masculine gender and explicitly addressed the issue of visibility of genders in texts, with the aim of finding solutions for gender-inclusive discursive practices (Žagar and Milharčič Hladnik 1995: 10-11). The members of the Slovene studies community who partook in the discussion did so in a constructive manner, albeit still with a pervasive understanding of language as a system (Stabej 1995: 28; Korošec 1995: 28). The unease of linguists dealing with Slovene studies in the widely open social discussion, which also addressed exceedingly sociological issues (Bahovec 1995), also resulted in the selection of the topic for the Seminar of the Slovenian Language, Literature and Culture, which put women in the center of interest of Slovene studies (Derganc 1997). This event, even to a much larger extent than the discussions of 1995, showed how the approaches of Slovene studies are exceedingly traditional as the lecturers for instance addressed the issues of etymology and onomastics (Jakopin 1997, Keber 1997), phraseology (Kržišnik 1997) or traditional lexicology (Vidovič Muha 1997). At the same time, the main linguistic position was recognized: that language is merely a reflection of the society, i.e. for linguistic change, we must first change the social reality (Vidovič Muha 1997). This was in direct contrast with the original idea of the 1995 discussion on the changes in language and discourse as being the drivers of social change (Bahovec 1995: 31).

The second half of the 1990s thus opened the discussion on the issue of sexual equality in language and the visibility of genders in discourse as well as established the foundations for a gender-inclusive use of Slovene, including the attempts to intervene in legislative discursive practices with the bill (that was never passed) proposing a two-gender version of the Slovenian legislation (Stabej 1997). One of the most tangible results of the 1990s discussions was the Standardized Classification of Professions, 5 in a version written for both genders. Even though this is

5 The current Standardized Classification of Professions from 2011 is available at https://www.stat.si/Skp/ Docs/MetodoloskaPojasnilaSKP08.pdf 
an important document that introduced consistent job descriptions for both men and women, this is still the segment of language, i.e. naming female actants with feminine noun forms, with which Slovene had had very few issues in the first place (Mečkovska 1980).

Since the end of the 1990s, gender linguistics has become an increasingly significant segment of linguistic discussions. Slovenian linguistics, especially the segment dealing with Slovene studies, is marked by traditionalism and has been trailing behind modern research activities in the humanities and social sciences in Europe (Gorjanc 2017: 12). And even though "linguists dealing with Slovenian have not been particularly interested in gender linguistics" (Doleschal 2015), this is actually more a problem of the entire post-structuralist field of Slovene studies as other topics covered by post-structuralist approaches are even more poorly researched. Recent linguistic research on gender thus touches upon interlinguistic comparisons (Kranjc and Ožbot 2013; Plemenitaš 2014) as well as different segments of communication in Slovene (Ščuka 2014, 2017). In the Nomotechnical Guidelines for Slovene ${ }^{6}$ (2008) the issue of gender is also addressed, and the interdisciplinary Handbook for Adopting Gender-Sensitive Approaches in Research and Teaching (Mihajlović Trbovc and Hofman 2016) also includes the field of gender-sensitive language, whereas some critical linguistic studies employ an explicitly engaged approach, aimed towards the community with a humanist desire to effect social changes for a greater equality of all people living in the Slovenian society. One of these is also the effort of trying to change discursive practices towards genderinclusive language using the underscore (Vičar and Kern 2017a, Vičar and Kern 2017b).

We therefore deal with the underscore extensively in the following sections. However, before we can discuss the use of the underscore as an innovative means of conveying gender-inclusive language, we must first outline the main tenets of expressing gender in Slovene, and then place the underscore within (or onto) this typology.

\section{Expressing gender in Slovene}

There are a number of ways of combining masculine and feminine forms in Slovene, used when there is a scarcity of space in play; in other cases, such contractions are not advisable (Kern and Dobrovoljc 2017):
a) Slash + hyphen (avtor/-ica)
b) Slash (zaposlen/a)
c) Brackets + hyphen $(\operatorname{rojen}(-a))$
d) Brackets $(\operatorname{rojen}(a))$
e) Hyphen (stanujoč-a)

6 Available at http://www.svz.gov.si/fileadmin/svz.gov.si/pageuploads/Dokumenti/Nomotehnicne_smer.pdf 
Traditionally, the masculine forms in Slovene are/were considered to be unmarked in terms of gender. However, this perspective has recently been met with criticism (Kern and Dobrovoljc 2017):?

In the last couple of decades, however, the unmarkedness of the masculine is no longer universally accepted, as its social context is ever more brought to the front. Thus, parallel feminine forms are increasingly being used. This has probably also increased the awareness that there is a difference between the natural (genetically defined) sex and [one's] sexual identity, and those who write want this difference expressed.

This quotation is of special significance as it was put forth by the de facto official language-standardizing body in Slovenia, the Fran Ramovš Institute of the Slovenian Language, Academy of Sciences and Arts of the Republic of Slovenia, albeit not in the traditional form of the normative language handbook (i.e. Pravopis 'orthography'), but on the official website of the Institute's Counseling Corner. ${ }^{8}$ As the latest edition of the orthography (Toporišič et al. 2001) is severely out of date (the draft was published as early as 1981) and is the primary source of language codification, the Counseling Corner may be understood as a reference (and, in some cases, as a quick aid) for various types of linguistic difficulties that the language users of Slovene are facing.

All five options listed above and provided by the Counseling Corner assume that there are two sexual identities, i.e. the male and female identities within a binary system. This is recognized by Kern and Dobrovoljc (2017), who add that

[t]here are also persons who do not identify (exclusively) with the male or female sex and whose sexual identity extends over the binary sexual system. In the last couple of years, the underscore is being adopted for the inclusion of non-binary sexual identities between the forms for the male and feminine. [...] This is characteristic not only for Slovene but for a number of languages in which gender is more clearly expressed than in, say, English. Among others, this includes the German language and Slavic languages.

All this means that the non-binary concept has been accepted or at least partly recognized by the central institutions dealing with language codification. However, when Kern and Dobrovoljc (2017) reported on the use of the underscore as a new

7 As stated by one of the faculty members of the Faculty of Arts, University of Ljubljana, at a senate meeting, she "refused to be [further] reduced to a footnote", thereby referring to the usual practice of providing a disclaimer upon the first mention of a masculine form with a footnote saying that the masculine forms used in the document are neutral and pertain to both genders.

See https://svetovalnica.zrc-sazu.si/o-svetovalnici. 
phenomenon in Slovene and added the sociolinguistic dimension to the understanding of this punctuation sign, this spurred much controversy in the Slovenian cultural environment. The use of the underscore, its aim and purpose as well as its adoption and reception are dealt with extensively in the following section.

\subsection{The underscore, its adoption and reception}

In this section, we aim to provide a detailed background on the adoption and reception of the underscore as a means of employing gender-inclusive language.

As already stated, the underscore was introduced as a means of overcoming the prevalent binary understanding of the distribution of sexes, which was engendered by and reflected in the use of the slash (meaning 'or'), unless an individual is comfortable with using it for themselves (Koletnik and Grm 2017: 22). Thus, it is a matter of linguistic/activist intervention for all genders that exist or may become existent in the future (Koletnik and Grm 2017: 22):

Unlike the slash (/), which still only offers two options and thereby creates a binary, the underscore connects both standard grammatical forms as well as separates them and, at the same time, creates an empty space between them, projecting endings that are not yet included in the linguistic norm, but may come about in the future. We use the underscore with grammatical forms that involve gender, in order to include all sexes, also those that surpass the sexual binarism woman - man. [...] The underscore is to be used if an individual uses such gender-neutral language [to refer to] in Slovene themselves.

This means that the use of the underscore is merely a recommendation to be taken into account especially when dealing with non-binary identifying persons, if these persons have a desire to be referred to in terms of gender-inclusive language. By creating an open space between both traditional poles (male vs. female), the underscore includes all genders, existent or otherwise, both in the visual sense (i.e., by creating a visual gap between the forms) as well as in grammatical terms (by serving as a means of punctuation).

The underscore is used extensively by the Slovenian organizations as well as online outlets dealing with the rights of the LGBTQ+ community. The main organizations are the following: Legebitra, TransAkcija, Dih, Škuc, Narobe, Open, The Peace Institute, Spol, LGBTpravice.

In addition to the above-listed organizations, a number of other enterprises and initiatives have also introduced the underscore to their style of writing, most notably the left-leaning political weekly Mladina (in its editorial), the editorial of the Kralji ulice magazine, the Institute Pekarna Magdalenske mreže, the ZaŽivali association (Kern and Dobrovoljc 2017) as well as in academia (cf. Hofman 2017 (ed.)). As stated by Šribar et al. (2016), in regard to introducing new ways of applying gender-inclusive language, it is "[e]xactly the fields of university and civil 
society that are most open and are opening further still to connect the democratizations of communities and language."

Due to the novelty (and, arguably, difficulty of use; see Štumberger 2018a, 2018b; Ferrari Stojanović 2018) of using the underscore when writing (and reading) in Slovene, there have been several issues raised over the following two aspects of using the underscore (Kern and Dobrovoljc 2017):

- The sequence of giving masculine and feminine forms (before and following the underscore)

- The linguistic element to follow the underscore (i.e. the entire affix or merely parts of it)

In addition to these two issues raised, there have also been concerns about the placement of the underscore within the Slovenian normative system (Štumberger 2018a, 2018b; Ferrari Stojanović 2018). We deal with these concerns in the following sections, here we focus merely on the manner of writing. As concerns the sequence, this is of no particular relevance. However, it would be prudent to use the masculine form first in cases where the feminine form is built using an affix to the male form (which is the root), as in učitelj_ica ('teacher'), režiser_ka ('director') or where there is a reduction in vowel (prišel_a 'came') (Kern and Dobrovoljc 2017). However, this would require that those who write in Slovene possess the knowledge about affixes and word-formation. Therefore, it is understandable that only those segments of words that are subject to variation when forming the feminine forms are normally put behind the underscore (Kern and Dobrovoljc 2017):

- zdravnik_ca or zdravnica_k,

- plural:zdravniki_ce or zdravnice_ki,

instead of:

- zdravnik_ica, zdravnik_nica or zdravnica_ik, zdravnica_nik,

- plural:zdravniki_ice, zdravniki_nice or zdravnice_iki, zdravnice_niki

The use of the underscore was also supported by FemA (Šribar et al. 2016), who claim that the

[p]erpetuated use of the generic masculine and its virtual neutrality subordinate women. It is dismissive towards persons who find themselves outside of the social division of men and women according to physicality. The language reflects reality, it refers to it and is, at the same time, the means of its creation.

The members of FemA also state that the increased awareness of the issues arising from grammar and lexicon regarding gender changed the overall narrative and that gender-inclusive language has become a sign of "cultural sophistication" (Šribar et al. 2016), adding that Slovene is flexible enough for one to convey something using gender-inclusive language without having to step outside the bounds of standard language. 
However, stepping outside the language rules is also advisable, as they are a matter of social consensus as well as its changes (Šribar et al. 2016). This is especially important due to the fact that language is of utmost importance in the Slovenian society. Mostly due to specific socio-political circumstances throughout the Slovenian history, the Slovenian society has developed a distinctive attitude towards language, marked mainly by conservatism and purism (cf. Urbančič 1961; Stabej 2000; Stabej 2012). This attitude had been further entrenched by the purist efforts of the last two centuries, and the notion of having to preserve the Slovenian language and protect it from powerful others persists to this day. As Thomas (1997:133) states,

[i]t is hardly surprising, given the cultural and political history of the Slovene people, that purism should have been such a salient factor in the formation and development of the Slovene Standard Language. The overwhelming presence over many centuries of the German language in Slovene intellectual and everyday urban life on the one hand and more recently the threat of competition from SerboCroatian in the fulfilment of many socio-communicative functions on the other can scarcely have failed to leave a profound impact on the linguistic attitudes of the Slovene people.

This has also influenced the Slovenian language policy, which is directive in nature (for the distinction between directive and liberal linguistic communities see Škiljan (1999)). This is, of course, significant due to the novelty of using the underscore, and there has been significant backlash against its adoption, for various reasons. As stated by Kern and Dobrovoljc (2017):

In Slovene, the use of the underscore is a novelty, but there is no need to deem it unacceptable in advance. According to those who are trying to implement it, it is the only method of writing that includes the entire society; [however] [1]inguistics has not yet deliberated upon the new modes of expression as they are - from the standpoint of syntax and use - poorly researched.

This has been one of the main foci of the discussion whether or not the underscore should be implemented or not, which again shows that the Slovenian cultural environment, in terms of language, is a very directive one. This means that the question of the underscore and its suitability should be given over to linguists who should deliberate on the matter and reach some sort of decision, as evidenced by the following passage (Štumberger 2018a) referring to the above-mentioned reply of the Counseling Corner (cf. Kern and Dobrovoljc 2017) of the Institute:

Uncritical assumption of the viewpoint of one of the activist groups without naming a source is unacceptable in a reply of the Counseling Corner. When judging upon the novelties in (literary) language, us 
linguists need to take into account language use, its system, tradition andlanguage economy, not to become heralds of a certain activist group.

In addition, the author (Štumberger 2018a) also states that the Institute's "reply that the use of the underscore was 'at first present within the transsexual community but became more general recently' will also have an effect on the future use of punctuation and also convince those who had previously thought differently. Or will someone dare doubt that?"

This was a vocal sign of protest against the introduction of the underscore as a means of gender-inclusive language in the Slovenian environment. However, there was also a "silent protest" as the following excerpt demonstrates (Štumberger 2018a):

I dared to respond and [...] published a response ${ }^{9}$ on the Slovlit forum [...], read by linguists, literary historians and those dealing with Slovene studies. Therefore, I was certain that the topic will attract other people to join the debate. It seems I was wrong as all the responses of my colleagues were delivered to me in private. I was also congratulated for my courage and saw that experts do not dare speak about the underscore, whereas the non-experts do not really know about it.

The blowback from the initial, exceedingly positive stance towards the use of the underscore had also contributed to the fact that the Counseling Corner issued another reply in regard to this issue, 10 this time signed by the editorial board of the service, as a reply to the following question (our emphasis):

\section{More and more often I see this sort of writings: Udeleženci_ke naj se zberejo $v$ avli ('The participants should meet in the lobby'). I'm curious if that's really necessary.}

The reply states that the discussion on the use of the underscore had received widespread attention and that the editorial board found it necessary to comment on the issue:

The purpose of the reply in the Counseling Corner is not to approve or disapprove of these linguistic choices, but merely to clarify that they exist and that they can be observed in various social groups. [...] We also view public responses and voiced opinions as an important part of research if we want linguistics to be truly based on data. In doing that, neither forbidding certain means of expression nor imposing our own reflects a mature stance towards language.

9 See Štumberger (2018b).

10 Available at https://svetovalnica.zrc-sazu.si/topic/3001/mno\%C5\%BEina-in-spoli-ponovno-o-pod\%C4 \%8Drtajih. 
The editorial board further touches upon the character of the replies within the Counseling Corner and its own role in the Slovenian linguistic community:

[T] he Counseling Corner was introduced as a means of quick aid with linguistic matters. The replies aim to be as authentic a summary of what is known about a linguistic phenomenon of [your] interest. If this knowledge contradicts the normative guides, that is explicitly stated. If, due to linguistic conditions that contrast those in the current normative guides, there is a change in the codification on the horizon, we aim to clarify and substantiate that. If we are dealing with an under-researched phenomenon, we explicitly state that. The replies in the Counseling Corner also reflect the opinions of the signed authors with which at least half of the editorial board agrees. The replies in the Counseling Corner do not constitute linguistic codification.

With this paragraph, the editorial board of the service sought to relativize its previous stance on the use of the underscore as well as to relativize its own credentials in terms of codification. It should be pointed out that this is the only reply in which the editorial board of the Counseling Corner saw fit to define its role in the Slovenian linguistic and academic community; this information is not even provided on the Counseling Corner website. The reply ends with the brief answer to the questioned posed by the user (written in bold in the above quotation): "Using the underscore is of course not necessary and left to your discretion. As already stated in the description of the guidelines, it depends on your beliefs and the personal message [you wish to convey] to the society."

\section{Corpus analysis}

In this section, we present the analysis of the two corpora built specifically for the purpose of studying the underscore as a new means of employing gender-inclusive language in Slovene.

\subsection{Study design}

Firstly, it needs to be pointed out that corpora represent a specific reality as they are built to represent a specific reality, although the representativeness is factored in the corpus-linguistic (Baker 1998: 50). This is very true also in our case as we are aiming to portray the use of a single linguistic element; what is more, we deliberately wish to include only those texts in the corpus that we know (or we at least presume) include what we are searching for. This means that we are building a corpus of Slovene that is representative as a whole of the object in question, i.e. the underscore. However, we still hold this language resource to be valid as it stands the test of all linguistic descriptions that come about on the basis of researching and analyzing corpora (Gorjanc and Fišer 2010: 10): 
- It aims to portray linguistic reality.

- It does not rely on intuition, even when faced with unexpected results.

- It includes several bits of information on the typical text environment and on the general reality of communication.

Thus, bearing these points in mind, to provide a solid research foundation for this paper, we constructed two (parallel) corpora using the WebBootCat function of the SketchEngine platform. Naturally, it would be prudent to use any of the existing corpora for Slovene. However, this was not possible as the existing corpora do not cover the most recent texts, whereas using the underscore is a very recent phenomenon in Slovene. This is especially relevant due to the fact that there have been attempts of analyzing the underscore and its frequency of use (see Štumberger 2018 b) by searching the Slovene reference corpus Gigafida for the use of the underscore, thereby ignoring the fact that this particular corpus only contains texts from 1991 up to 2011. Wishing to avoid any subjectivity, we thus concluded that building a new language resource is an unavoidable step.

For this reason, we automatically harvested texts from various online sources that use the underscore. These are the following: Legebitra ${ }^{11}$, TransAkcija12, Dih ${ }^{13}$, Škuc $^{14}$, Narobe ${ }^{15}$, Open ${ }^{16}$, The Peace Institute ${ }^{17}$, Spol.si' ${ }^{18}$, and LGBTpravice ${ }^{19}$.

We constructed the first corpus (termed EquiCorpus) end of March 2018, and the second one (EquiCorpus 2) end of September 2018, in order to allow six months of time to determine:

a) whether or not the use of the underscore is prolific

b) whether or not the use of the underscore is consistent

c) whether or not different organizations and the key actors in the LGBTQ+ community (and/or the supporters thereof) had been using the underscore comparatively extensively

We aim to provide answers to these research questions in the following section.

\subsection{Corpora analysis}

Both corpora were constructed in exactly the same way, containing exactly the same sources. In this way, we tried to ensure that the results are as valid as possible. The characteristics of both corpora are given in Table 1.

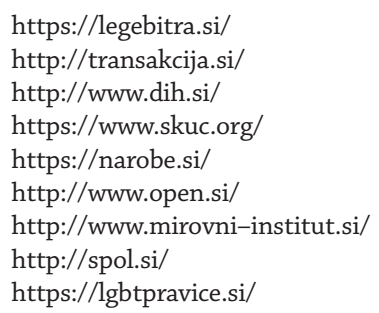




\begin{tabular}{|l|r|r|c|}
\hline \multicolumn{1}{|c|}{ Category } & EquiCorpus & EquiCorpus 2 & Difference (+/-\%) \\
\hline Tokens & $2,057,800$ & $2,408,421$ & +14.6 \\
\hline Words & $1,644,925$ & $1,936,544$ & +15.1 \\
\hline Sentences & 86,238 & 93,941 & +8.2 \\
\hline Paragraphs & 28,565 & 19,061 & -33.3 \\
\hline Documents & 1,766 & 1,282 & -27.4 \\
\hline
\end{tabular}

Table 1: Characteristics of EquiCorpus and EquiCorpus 2.

As Table 1 demonstrates, the increase in size from EquiCorpus to EquiCorpus 2 in tokens and words is significant (roughly 350,000 and 300,000, respectively), even though a significant decrease in number is discernible in the categories of paragraphs and documents, and especially when taking into account the fact that we were not able to harvest the texts from one of the websites due to technical restrictions. ${ }^{20} \mathrm{On}$ the basis of the figures given in Table 1 , we can conclude that even though the structure of the websites in question had (apparently) changed and/or the missing domain contributed a high number of documents (with a high number of paragraphs), the content of the websites grew considerably. This difference in size (in terms of words and tokens) shows that all domains are very much active and thus provide a suitable source of information for our research. ${ }^{21}$

As the domains grew in size in terms of words and tokens, it is vital to research whether or not the number of words used with the underscore grewby (atleast) the same margin. Therefore, the frequency of tokens used with the underscore is given in Table 2 .

\begin{tabular}{|l|c|c|c|}
\hline \multicolumn{1}{|c|}{ Category } & EquiCorpus & EquiCorpus 2 & Difference (+/-\%) \\
\hline $\begin{array}{l}\text { Words with the underscore } \\
\text { (total frequency) }\end{array}$ & 1689 & 4667 & +63.8 \\
\hline $\begin{array}{l}\text { Items (unique words) with } \\
\text { the underscore }\end{array}$ & 177 & 355 & +50.1 \\
\hline Average & $/$ & $/$ & $+56.95 \%$ \\
\hline
\end{tabular}

Table 2: Words containing the underscore in EquiCorpus and EquiCorpus 2.

As Table 2 demonstrates, there has been a significant increase (63.8\%) in the number of the words used with the underscore in EquiCorpus compared to the original corpus, especially when we consider that the total word count of the corpus only

20 We were unable to harvest texts from the domain www.skuc.org. This accounts for a loss of at least 112,842 words in EquiCorpus 2 compared to EquiCorpus; however, it is very likely that the loss is greater as it would be natural to expect that the domain grew in size in the last six months. In spite of that, we elected not to perform any other procedures that would include the texts from the original corpus in EquiCorpus 2, as this would compromise the integrity of our research data.

21 The complete wordlists from both corpora are available for download and further inspection/research in the form of Microsoft Excel spreadsheets. The EquiCorpus wordlist is available at https://www.dropbox.com/s/ t0nlsisunik51a4/wordlist_equicorpus.xlsx?dl=1, and the EquiCorpus 2 wordlist at https://www.dropbox. com/s/4g9sl3dsb10fnpt/wordlist_equicorpus_2_.xlsx?dl=1. 
grew by a $14.6 \%$ margin. This means that the use of the underscore is prolific and that its rate of use (speaking at least for the time period in question) is rapidly increasing.

A further point to be considered is the variability of use of the underscore. This can be observed in the category Tokens in Table 2. Tokens are unique (i.e. singular) words used with the underscore. The number of tokens grew by more than half (i.e. $50.1 \%$ ), signifying that the use of the underscore is not only prolific, but also diversified as there have been a number of words used with the underscore that had not yet been used thusly in EquiCorpus. For this reason, we are supplying the most frequent words used in EquiCorpus and EquiCorpus 2 in Tables 3 and 4, respectively. ${ }^{22}$

\begin{tabular}{|l|c|}
\hline \multicolumn{1}{|c|}{ Word } & Count \\
\hline vabljene_i & 54 \\
\hline partner_ka & 42 \\
\hline zapisale_i & 39 \\
\hline vprašale_i & 37 \\
\hline migrantke_i & 33 \\
\hline posameznice_ka & 32 \\
\hline bile_i & 28 \\
\hline posameznic_kov & 25 \\
\hline vse_i & 24 \\
\hline partnerja_ke & 23 \\
\hline akterk_jev & 21 \\
\hline same_i & 20 \\
\hline sam_a & 20 \\
\hline bil_a & 19 \\
\hline partnerja_ki & 17 \\
\hline zdravnici_ku & 17 \\
\hline dobrodošle_i & 16 \\
\hline begunk_cev & 16 \\
\hline imele_i & 16 \\
\hline *banner_lj_exh & 15 \\
\hline zdravnice_ka & 15 \\
\hline delavk_cev & 15 \\
\hline aktivistke_i & 15 \\
\hline dedič_nja & 14 \\
\hline ustvarjalkam_cem & 14 \\
\hline
\end{tabular}

\begin{tabular}{|l|c|}
\hline zdravnice_ki & 14 \\
\hline mladostnice_ki & 14 \\
\hline obiskovalke_ci & 13 \\
\hline naleteli_e & 13 \\
\hline rad_a & 13 \\
\hline posameznice_ke & 12 \\
\hline razglasile_i & 11 \\
\hline udeleženke_ci & 11 \\
\hline sodelavci_kami & 10 \\
\hline bralke_ce & 10 \\
\hline begunkam_cem & 10 \\
\hline partnerjev_ic & 10 \\
\hline pripravile_i & 10 \\
\hline sodelavci_ke & 10 \\
\hline zdravnik_ca & 10 \\
\hline partnerju_ki & 10 \\
\hline izvedle_i & 10 \\
\hline nekatere_i & 10 \\
\hline transspolne_i & 10 \\
\hline imel_a & 10 \\
\hline dopolnil_a & 10 \\
\hline obiskovalec_ka & 10 \\
\hline same_ga & 10 \\
\hline vložile_i & 9 \\
\hline slišali_e & 9 \\
\hline
\end{tabular}

Table 3: The most frequent words containing the underscore in EquiCorpus.

22 The example that represents noise (i.e. the example banner_lj_exh) is marked with an asterisk. This also points to a potential flaw of the asterisk as a new means of expressing gender-inclusive language, as it is very frequent in filenames, web addresses, etc. 


\begin{tabular}{|l|c|}
\hline \multicolumn{1}{|c|}{ Word } & Count \\
\hline vabljene_i & 255 \\
\hline vse_i & 159 \\
\hline delil_a & 132 \\
\hline posameznice_ka & 68 \\
\hline ustvarjalkam_cem & 67 \\
\hline same_i & 57 \\
\hline delavk_cev & 53 \\
\hline me_i & 53 \\
\hline bile_i & 51 \\
\hline zapisale_i & 49 \\
\hline srečna_en & 48 \\
\hline posameznic_kov & 45 \\
\hline zdravnice_ka & 45 \\
\hline partner_ka & 42 \\
\hline udeležile_i & 42 \\
\hline tiste_i & 41 \\
\hline bil_a & 39 \\
\hline vprašale_i & 38 \\
\hline obiskovalke_ce & 36 \\
\hline sam_a & 34 \\
\hline gledalkam_cem & 33 \\
\hline akterk_jev & 33 \\
\hline slikarje_ke & 32 \\
\hline plesalce_ke & 32 \\
\hline gledališčnike_ce & 32 \\
\hline &
\end{tabular}

\begin{tabular}{|l|l|}
\hline glasbenike_ce & 32 \\
\hline zablestele_i & 32 \\
\hline udeleženke_ci & 32 \\
\hline lgbtq-ustvarjalce_ke & 31 \\
\hline imele_i & 31 \\
\hline vsak_a & 30 \\
\hline obiskovale_i & 29 \\
\hline posameznice_ki & 29 \\
\hline nekatere_i & 28 \\
\hline partnerja_ke & 24 \\
\hline dobrodošle_i & 24 \\
\hline pripravile_i & 22 \\
\hline aktivistke_i & 22 \\
\hline prostovoljke_ci & 21 \\
\hline zdravnici_ku & 21 \\
\hline delavke_ci & 21 \\
\hline imel_a & 21 \\
\hline posameznice_ke & 21 \\
\hline ve_i & 21 \\
\hline migrantke_i & 20 \\
\hline pogovarjale_i & 20 \\
\hline dobile_i & 19 \\
\hline prostovoljk_cev & 19 \\
\hline delavkami_ci & 18 \\
\hline poskušale_i & 18 \\
\hline
\end{tabular}

Table 4: 50 most frequent words containing the underscore in EquiCorpus 2.

As Tables 3 and 4 demonstrate, the most frequent word used with the underscore remained the same in both corpora (vabljene_i '[you are] invited'). The frequency of this word grew considerably (i.e. by 78.9\%), which can be attributed to the fact that it is a very common expression used in addressing people in invitations and descriptions of events. If we observe the ten most common words used with the underscore, we can notice several differences, however: 


\begin{tabular}{|l|c|l|c|}
\hline Word(EquiCorpus) & Count & Word(EquiCorpus 2) & Count \\
\hline vabljene_i & 54 & vabljene_i & 255 \\
\hline partner_ka & 42 & vse_i & 159 \\
\hline zapisale_i & 39 & delil_a & 132 \\
\hline vprašale_i & 37 & posameznice_ka & 68 \\
\hline migrantke_i & 33 & ustvarjalkam_cem & 67 \\
\hline posameznice_ka & 32 & same_i & 57 \\
\hline bile_i & 28 & delavk_cev & 53 \\
\hline posameznic_kov & 25 & me_i & 53 \\
\hline vse_i & 24 & bile_i & 51 \\
\hline partnerja_ke & 23 & zapisale_i & 49 \\
\hline
\end{tabular}

Table 5: 10 most common words with the underscore in both corpora.

As Table 5 demonstrates, there has been a notable increase in the pronoun vse_i (all) and function words in general (written in bold in Table 5). What should also be noted is the high occurrence (in both corpora) of words pertaining to individuals (posameznice_ka,posameznic_kov) and their occupations (ustvarjalkam_cem 'artists', delavk_cev 'workers').

This is also reflected in both corpora: if we look at both lists as a whole (cf. Tables 3 and 4 as well as the whole lists of words used with the underscore), we can identify roughly the following categories (in terms of function and topic):

1. function words and auxiliary verbs

2. verbs dealing with cognitive functions or functions related to cognizance (vprašale_i,zapisale_i)

3. nouns relating to individuals

4. nouns relating to occupations

5. nouns relating to migrants and other marginalized groups as well as the people acting on their behalf

6. nouns relating to healthcare (in terms of providing access to healthcare and health services for said marginalized groups

7. nouns relating to marital/relationship statuses

As we can deduct from the list above, the topicality of the words (and, hence, texts) using the underscore is closely connected to the LGBTQ+ community, its members and main focus points of their organizing and activist efforts, as well as with other groups that have been faced with hardships and social injustice. 


\section{Conclusions}

In this paper, we tried to depict the efforts of employing gender-inclusive language in the Slovenian cultural environment in the last two decades. These have been marred with significant progress in several fields (as in the introduction of the standardized nomenclature of all vocations for men and women as well as in the successful shift of the discussion towards benevolence in matters dealing with the rights of the LGBTQ+ community and other marginalized groups). However, there are several issues that have been brought to light, especially with the latest developments in adopting gender-inclusive language. One of them is the exceedingly traditionalist views of gender, especially in the field of Slovene studies, in which the key figures do not shy away from employing manipulative acts to push the traditionalist doctrine. The second issue that is discernible in the field of Slovene studies is that of methodology as Slovene studies is marred by regressionist quasi-structuralist approaches, both in their view of gender (which is normally limited to being merely a grammatical category) as well as in their view of the role that language plays in the society (i.e. that it is by no means the driver of social change, merely its reflection).

We provided ample background to describe the state of affairs in the Slovenian cultural environment, focusing mainly on the recent developments, especially those connected to the introduction of the underscore used inventively to make the use of Slovene more gender-inclusive. To this end, we described the role of the underscore in detail, as well as its adoption and reception. As already pointed out, the underscore caused much controversy in Slovenia and was faced with significant resistance. As one of the major counter-arguments for the introduction of the underscore was its supposed disuse, we furnished our research by means of corpus analysis, in order to determine whether or not

1. the use of the underscore is prolific;

2. the use of the underscore is consistent and whether or not different organizations and the key actors in the LGBTQ+ community (and/or the supporters thereof) had been using the underscore comparatively extensively.

As concerns the prolific use of the underscore, we may safely say that it is very much being used in the LGBTQ+ community and several other cultural/media outlets. This is attested by the significant increase in number of words and tokens in the last six-month period. Drawing from the fact that both corpora that we constructed portray the most up-to-date version of Slovene (albeit, in a particular community, and in a pre-defined selection of sources), we may also assume that the ubiquity of this linguistic element accounts for its acceptance in said community. Of course, this does not mean that the underscore is a means of general written communication in Slovene, and this could hardly be proven with the manually constructed corpora we built for the purposes of this research. However, it is a relevant 
means of using gender-inclusive language within the community that is especially vocal in this respect and can hardly be expected to be adopted by a wider margin of speakers of Slovene within such a limited time span.

In terms of consistency, we can say that - upon looking at the wordlists obtained from the corpora - the writers who use the underscore use it remarkably consistently as we can hardly find different versions/spellings of words written with an underscore. Thus, one of the main criticisms of the underscore (that it is hard to use) seems to be invalid, at least in our database. On the other hand, the frequency lists show that there is some variation at the level of lexical choices as some of the most frequent words in EquiCorpus 2 are different to those in the original corpus, which shows that the underscore, at least in the community that is covered by our database, is a dynamic linguistic element, performing its intended function.

\section{References}

Ahačič, Kozma (2018). Janez Novak, študentka slovenščine. Delo 27. 5. 2018.

https://www.delo.si/novice/slovenija/janez-novak-studentka-slovenscine-54157.html

Bahovec, Eva D. (1995). Zapis javne strokovne razprave. Kozmik, Vera and Jasna Jeram, eds. Neseksistična raba jezika. Ljubljana: Vlada Republike Slovenije, Urad za žensko politiko, 30-31

Bajec, Anton, Rudolf Kolarič and Mirko Rupel (1956). Slovenska slovnica. Ljubljana: Državna založba Slovenije

Baker, Mona (1998). Routledge Encyclopaedia of Translation Studies. London: Routledge

Derganc, Aleksandra (ed.) (1997). Ženska v slovenskem jeziku, literature in kulturi. XXXIII. seminar slovenskega jezika, literature in kulture. Ljubljana: Filozofska fakulteta, Oddelek za slovanske jezike in književnosti

Doleschal, Ursula (2015). Gender in Slovenian. Hellinger, Marlis and Heiko Motschenbacher, eds. Gender Across Languages: Volume 4. Amsterdam/Philadelphia: John Benjamins, 333-368

Ferrari Stojanovič, Uroš (2018). Re: Podčrtaj namesto poševnice. Slovlit. https://mailman.ijs.si/pipermail/slovlit/2018/006233.html.

Golež Kaučič, Marjetka (2018). Slovenska ljudska balada. Ljubljana: Založba ZRC, ZRC SAZU

Gorjanc, Vojko (2005). Neposredno in posredno žaljiv govor v jezikovnih priročnikih: diskurz slovarjev slovenskega jezika. Družboslovne razprave 21(48): 197-209

Gorjanc, Vojko (2017). Nije rečnikza seljaka. Beograd: Biblioteka XX vek

Gorjanc, Vojko (2018). Slovene Standard-language Ideology: National Elitism and Exclusion. Abstract. Sociolinguistics Symposium 22.

http://programme.exordo.com/ss22/delegates/presentation/91/

Gorjanc, Vojko and Darja Fišer (2010). Korpusna analiza. Ljubljana: Znanstvena založba Filozofske fakultete $v$ Ljubljani

Hofman, Ana (ed.) (2017). Znanost (brez) mladih. Zgodnje stopnje znanstvene kariere skozi perspektivo spola. Ljubljana: Založba ZRC, ZRC SAZU 
Jakopin, Franc (1997). Ženskost v slovanskih priimkih. Derganc, Aleksandra, ed. Ženskav slovenskem jeziku, literature in kulturi. XXXIII. seminar slovenskega jezika, literature in kulture. Ljubljana: Filozofska fakulteta, Oddelek za slovanske jezike in književnosti, 25-31

Katnić-Bakaršić, Marina (2012). Između diskursa moći i moći diskursa. Zagreb: Naklada ZORO

Keber, Janez (1997). Ženska imena v Sloveniji. Derganc, Aleksandra, ed. Ženska v slovenskem jeziku, literature in kulturi. XXXIII. seminar slovenskega jezika, literature in kulture. Ljubljana: Filozofska fakulteta, Oddelek za slovanske jezike in književnosti, 33-43

Kern, Boris (2015). Politična korektnost v slovaropisju. Zuljan Kumar, Danila, Dobrovoljc, Helena, eds. Škrabčevi dnevi 8. zbornik prispevkov s simpozija 2013. Nova Gorica: Založba Univerze v Novi Gorici, 144-154

Kern, Boris and Helena Dobrovoljc (2017). Pisanje moških in ženskih oblik in uporaba podčrtaja za izražanje »spolne nebinarnosti«. Jezikovna svetovalnica. https://svetovalnica. zrc-sazu.si/topic/2247/pisanje-mo\%C5\%A1kih-in-\%C5\%BEenskih-oblik-in-uporaba-pod\%C4\%8Drtaja-za-izra\%C5\%BEanje-spolne-nebinarnosti

Koletnik, Anja and Evan Ana Grm (2017). Priročnik za medijsko poročanje o transspolnosti. Ljubljana: Zavod Transfeministična iniciativa TransAkcija

Korošec, Tomo (1995). Zapis javne strokovne razprave. Kozmik, Vera and Jasna Jeram, eds. Neseksistična raba jezika. Ljubljana: Vlada Republike Slovenije, Urad za žensko politiko, 27-29

Kranjc, Simona and Martina Ožbot (2013). Vloga spolno občutljivega jezika v slovenščini, angleščini in italijanščini. Žele, Andreja, ed. Družbena funkcijskost jezika (vidiki, merila, opredelitve). Obdobja 32. Ljubljana: Znanstvena založba Filozofske fakultete, 233-239

Kržišnik, Erika (1997). Kdo govori kako. Derganc, Aleksandra, ed. Ženska v slovenskem jezi$k u$, literature in kulturi. XXXIII. seminar slovenskega jezika, literature in kulture. Ljubljana: Filozofska fakulteta, Oddelek za slovanske jezike in književnosti, 45-56

Mečkovska, Nina (1980). Samostalniški spol v slovenskem in vzhodnoslovanskih jezikih. Slavistična revija 28(2): 199-218

Mihajlović Trbovc, Jovana and Ana Hofman (2016). Priročnikza uvajanje spolno občutljivega pristopa $v$ raziskovanje in poučevanje. Ljubljana: Založba ZRC, ZRC SAZU

Nomotehnične smernice. 2., spremenjena in dopolnjena izdaja. Ljubljana: Uradni list Republike Slovenije (2008)

Plemenitaš, Katja (2014). Gender ideologies in English and Slovene: a contrastive view. ELOPE 11 (1): 17-29

Recommendation no. $R$ (90) 4 of the Committee of ministers to member states on the elimination of sexism from language (1990). https://rm.coe.int/1680505480

Resolution on policy and strategies for achieving equality in political life and in the decision-making process (1986)

Slovar novejšega besedja slovenskega jezika. Elektronska objava. Ljubljana: Založba ZRC, Znanstvenoraziskovalni center SAZU (2014)

Slovar slovenskega knjižnega jezika. Druga, dopolnjena in deloma prenovljena izdaja. Elektornska objava. Ljubljana: Založba ZRC, Znanstvenoraziskovalni center SAZU (2014). 
Slovar slovenskega knjižnega jezika. Ljubljana: Državna založba Slovenije (1970-1991)

Snoj, Marko, Tina Lengar Verovnik and Helena Dobrovoljc (2016). Kateri od zapisov - »učenec/-ka«ali »učenec/ka« - je ustreznejši? Jezikovna svetovalnica. https://svetovalnica. zrc-sazu.si/topic/1636/kateri-od-zapisov-u\%C4\%8Denec-ka-ali-u\%C4\%8Denecka-je-ustreznej\%C5\%A1i.

Stabej, Marko (1995). Zapis javne strokovne razprave. Kozmik, Vera and Jasna Jeram, eds. Neseksistična rabajezika. Ljubljana: Vlada Republike Slovenije, Urad za žensko politiko, 25-27

Stabej, Marko (1997). Seksizem kot jezikovnopolitični problem. Derganc, Aleksandra, ed. Ženska v slovenskem jeziku, literature in kulturi. XXXIII. seminar slovenskega jezika, literature in kulture. Ljubljana: Filozofska fakulteta, Oddelek za slovanske jezike in književnosti, 57-68

Stabej, Marko (2000). Dvotirnost normativnosti v sodobnem slovenskem knjižnem jeziku. Badurina, Lada, Boris Pritchard, and Diana Stolac, eds. Jezična norma i varijeteti. Zagreb, Rijeka: Hrvatsko društvo za primijenjenu lingvistiku. 511-515

Stabej, Marko (2012). Jezik, nazori in nadzor. Bjelčevič, Aleš, ed. Ideologije v slovenskem jeziku, literaturi in kulturi. 48. seminar slovenskega jezika, literature in kulture. Ljubljana: Znanstvena založba Filozofske fakultete, 11-20

Sušec Michieli, Barbara et al. (2007). Gledališki terminološki slovar. Ljubljana: Založba ZRC, ZRC SAZU

Ščuka, Nuša (2014). Jezik in spol. Jezikoslovni zapiski 20(2): 79-88.

Ščuka, Nuša (2017). Spolno občutljiva raba jezika v spontanem formalnem javnem diskurzu. Zupan Sosič, Alojzija, ed. Ljubezen v slovenskem jeziku, literaturi in kulturi. 53. seminar slovenskega jezika, literature in kulture. Ljubljana: Znanstvena založba Filozofske fakultete, 131-134

Škiljan, Dubravko (1999). Javni jezik: k lingvistiki javne komunikacije. Ljubljana: Studia Humanitatis

Šorli, Mojca (2018). Lepo je, da smo vključevalni, nerodno pa, da smo to zgolj takrat, ko nam ustreza. Metina lista. Mnenja. https://metinalista.si/lepo-je-da-smo-vkljucevalni-nerodno-pa-da-smo-to-zgolj-takrat-ko-nam-ustreza/

Šribar, Renata, Barbara Korun, Polona Mesec, Vesna Leskošek, Nina Perger, Tanja Rener, Alja Adam, Luna Jurančič Šribar and Mirjana Ule (2016). Pomembnost uporabe obojespolskih samostalnikov s podčrtajem (»učiteljice_ji«). Torek ob petih. http://torekobpetih.si/odprtina/pomembnost-uporabe-obojespolskih-samostalnikov-s-podcrtajem-uciteljice_ji/

Štumberger, Saška (2018a). Transspolnost v slovenščini: Bomo nekoč pisali "povabili_e so ga_jo k sodelovanju«? Portal PLUS. https://www.portalplus.si/2668/uvajanje-podcrtaja-za-izrazanje-spolne-nebinarnosti/

Štumberger, Saška (2018b). Simpozij Jezikovne politike v luči nediskriminacije in politične korektnosti: tendence in spremembe v slovanskih jezikih. Slovlit. https://mailman.ijs.si/pipermail/slovlit/2018/006279.html.

Thomas, George (1997). The Impact of Purism on the Development of the Slovene Standard Language. Slovene Linguistic Studies 1: 133-152.

https://doi.org/10.17161/SLS.1808.800 
Trojar, Mitja and Mojca Žagar Karer (2013). Družbena občutljivost v terminoloških slovarjih. Žele, Andreja, ed. Družbena funkcijskost jezika (vidiki, merila, opredelitve)/The Social Functionality of Language (Aspects, Criteria, Defenitions). Obdobja 32. Ljubljana: Center za slovenščino kot drugi/tuji jezik, 457-463

Toporišič, Jože (1976). Slovenska slovnica. Maribor: Založba Obzorja

Toporišič, Jože (1981). K teoriji spola v slovenskem (knjižnem) jeziku. Slavistična revija 29 (1): 79-94

Toporišič, Jože (2004). Slovenska slovnica. Četrta, prenovljena in razširjena izdaja. Maribor: Založba Obzorja

Toporišič, Jože et al. (2001). Slovenski pravopis. Ljubljana: Založba ZRC, ZRC SAZU

Urbančič, Boris (1961). O kriterijih pravilnosti v knjižni slovenščini. Jezik in slovstvo 6(3), 81-87

Vičar, Branka and Boris Kern (2017a). Možnosti jezikovnega izražanja nebinarnih transspolnih identitet $\mathrm{v}$ slovenščini/The potential for linguistic expression of non-binary transgender identities in Slovene. Engendering difference: sexism, power and politics. Book of abstracts. Maribor: Filozofska fakulteta, Univerza v Mariboru, 37

Vičar, Branka and Boris Kern (2017b). Možnosti jezikov - nega izražanja nebinarnih transspolnih identitet v slovenščini. Dialogi 53(11/12): 223-237

Vidovič Muha, Ada (1997). Prvine družbene prepoznavnosti ženske prek poimenovalne tipologije njenih dejavnosti, lastnosti. Derganc, Aleksandra, ed. Ženska v slovenskem jeziku, literature in kulturi. XXXIII. seminar slovenskega jezika, literature in kulture. Ljubljana: Filozofska fakulteta, Oddelek za slovanske jezike in književnosti, 69-79.

Vojaški slovar. Ljubljana: Partizanska knjiga (1977)

Žagar, Igor Ž. and Mirjam Milharčič Hladnik (1995). Temeljna izhodišča prizadevanj za odpravo seksistične rabe jezika. Kozmik, Vera and Jasna Jeram, eds. Neseksistična raba jezika. Ljubljana: Vlada Republike Slovenije, Urad za žensko politiko, 7-18

\section{Izazovi uvođenja rodno osjetljivoga jezika u slovenskome jeziku}

U ovome radu predstavljamo izazove uvođenja rodno osjetljivoga jezika u slovenski jezik u proteklim dvama desetljećima. Slijedom toga usredotočili smo se na progresivne pomake na području uvođenja rodno osjetljivoga jezika i predstavit ćemo cjelovitu pozadinu toga razvoja, što uključuje i suprotstavljenu stranu (i njihove argumente), koja radi na tome da poništi napore uložene u uvođenje i primjenu rodno osjetljivoga jezika u slovenskome društvu. U radu ćemo pružiti pregled glavnih tendencija te jezičnih elemenata kojima se koristi s ciljem lakšega uvođenja i usvajanja rodno osjetljivoga jezika u slovenskome društvu, s glavnim naglaskom na upotrebu donje crte u pismu. U radu se analiziraju dva ručno izrađena korpusa tekstova prikupljenih sa slovenskih mrežnih stranica onih organizacija koje upotrebljavaju donju crtu radi primjene rodno osjetljivoga jezika. Analizom tih podataka pokazat ćemo da se donja crta svečešće upotrebljava unatoč naporima da se umanji učinak njezine primjene tako što se dovodi u pitanje upotrebljivost i prisutnost toga elementa.

Keywords: gender linguistics, discourse studies, Slovene

Ključne riječi: lingvistika roda, istraživanja diskursa, slovenski jezik 